\title{
FAKTOR-FAKTOR YANG MEMPENGARUHI KUALITAS PENGELOLAAN LINGKUNGAN TERHADAP KONDISI DI BANTARAN HILIR SUNGAI MUSI KECAMATAN GANDUS KOTA PALEMBANG
}

\author{
Helfa Septinar ${ }^{1}$, Ratna Wulandari Daulay ${ }^{2}$, Mega Kusuma Putri ${ }^{3}$ \\ ${ }^{123}$ Pendidikan Geografi Universitas PGRI Palembang \\ (邓) Helfa23@yahoo.com ${ }^{1}$, ratnadaulay@gmail.com ${ }^{2}$, puteri.mega@ rocketmail.com ${ }^{3}$
}

\begin{abstract}
ABSTRAK
Peningkatan kebutuhan manusia dan berkurangnya lahan untuk berusaha memacu peningkatan degradasi lingkungan perairan Sungai. Kualitas lingkungan hidup semakin menurun ini berarati bahwa pengelolaan lingkungan yang telah dicanangkan pemerintah dengan undang-undang yang berlaku, masih tidak sesuai dengan kenyataan lingkungan yang ada. Dalam kenyataan bahwa lingkungan di bantaran sungai Musi yang berada di kecamatan Gandus pengelolaannya belum sesuai dengan peraturan perundang-undangan yang berlaku. Dalam hal ini berarti ada faktor-faktor yang mempengaruhi pengelolaan lingkuangan tersebut. Berdasarkan perjalasan diatas tujuan penelitian ini adalah untuk mengetahui factor-faktor yang mempengaruhi kualitas pengelolan lingkungan terhadap bantaran sungai Musi di kecamatan Gandus Kota Palembang. Adapun metode yang digunakan adalah kualitatif dengan pendekatan deskkriptif empirik. Hasil yang didapat bahwa faktor-faktor soaial ekonomo saling berkaitan satu sama lain. Tingkat pendidikan yang rendah yaitu taman SD atau tidak tamat SD 64\%, memiliki pekerjaan sebagai buru/kuli/tidak kerja $86 \%$, kepemilikan rumah $82 \%$, dan perilaku masyarakat dalam membuang sampah dilahan terbuka $32 \%$, memanfaatkan sungai sebagai tempat mandi, mencuci, dan industri sebanyak $82 \%$ dan membuang limbah WC langsung kesungai 22\%. Dan dapat disimpulkan dari hasil persentase dengan kenyataan di lapangan bahwa terdapat mempengaruhi faktor sosial ekonomi terhadap kualitas pengelolaan lingkungan.
\end{abstract}

Kata Kunci: Faktor-faktor Sosial Ekonomi, Pengelolaan Lingkungan

\section{PENDAHULUAN}

Sungai Musi tergolong sungai besar yang bermuara ke pantai timur Sumatera Selatan. Daerah Aliran Sungai Musi (DAS) membentang antara $1^{\circ} 40^{\prime} \mathrm{LS}$ sampai $5^{\circ} \mathrm{LS}$ dan $120^{\circ} 7^{\prime} \mathrm{BT}$ sampai $105^{\circ} 7^{\prime} \mathrm{BT}$. Morfologi sungai Musi dari hulu kehilir terbagi atas tiga ekologi, yaitu (1) tipe perairan berarus deras samap sedang, (2) tipe peraian berarus tenang, dan (3) tipe perairan yang dipengaruhi pasang surut ke laut. Sungai Musi bagian hilir mulai dari Desa Tebing Abang, Kabupaten Muara Enim hingga ke muara Selat Bangka di Desa Sungsang Kabupaten Banyuasin (Ngurah . 2010).

Sungai Musi merupakan salah satu tipe sungai permanen di Pulau Sumatera yang memiliki tipe ekosistem yang komplek dengan jenis dan tingkat pemanfaatan perairan yang beragam (Husnah. 2010). Peningkatan kebutuhan manusia dan berkurangnya lahan untuk berusaha memacu peningkatan degradasi lingkungan perairan Sungai. Tekanan terhadap peningkatan lingkungan dapat berbentuk perubahan fisik lingkungan atau modifikasi lingkungan atau penambahan bahanbahan hasil kegiatan manusia baik bahan yang bersifat beracun atau tidak beracun (Husnah. 2010)

Kualitas lingkungan hidup yang semakin menurun telah mengancam keberlangsungan perikehidupan manusia dan makhluk hidup lainnya sehingga perlu dilakukan perlindungan dan pengelolaan lingkungan hidup yang sungguhsungguh dan konsisten oleh semua pemangku kepentingan (UU No. 32 tahun 2009). Kualitas 
lingkungan hidup semakin menurun ini berarati bahwa pengelolaan lingkungan yang telah dicanangkan pemerintah dengan undang-undang yang berlaku, masih tidak sesuai dengan kenyataan lingkungan yang ada. Kecamatan Gandus di bantaran sungai Musi, bahwa keadaan lingkungan tersebut termasuk yang memiliki kualitas ligkungan yang menurun. Bahwa di bantaran sungai di kecamatan gandus masih banyaknya sampah yang bertebaran karena masyarakat disana banyak yang membuang sampah langsung kesungai ataupun lingkungan sekitar.

Dalam kenyataan bahwa lingkungan di bantaran sungai Musi yang berada di kecamatan Gandus pengelolaannya belum sesuai dengan peraturan perundang-undangan yang berlaku. Dalam hal ini berarti ada faktor-faktor yang mempengaruhi pengelolaan lingkuangan tersebut. Hal ini berpengaruh dari tingkat kesadaran masyarakat terhadap lingkungan sekitar tempat tinggal mereka. Menurut Daniel Chiras (Neolaka; 2008) kesadaran lingkungan adalah etika lingkungan. Etika lingkungan yang sampai saat ini berlaku adalah etika lingkungan yang didasarkan pada sistem nilai yang mendudukkan manusia bukan bagian dari alam, tetapi manusia sebagai penakluk dan pengatur alam.

Didalam pendidikan lingkungan hidup, konsep mental tentang manusia sebagai penakluk alam perlu diubah menjadi manusia sebagian dari alam. Kesadaran adalah pengetahuan. Sadar sama dengan tahu. Pengetahuan yang mendalam (menggugah jiwa), tahu sungguh-sungguh, dan tidak tahu. Tidak asal mengetahui/tahu. Sebab banyak orang tahu pentingnya lingkungan hidup tetapi belum sadar karena tindakan/perilaku merusak lingkungan/tidak mendukung terciptanya kelestarian lingkungan hidup. Dalam hal ini kurang tahu atau kurang kesadaran tehadap tindakan/perilaku ini disebabkan adanya faktorfaktor yang mempengaruuhi. Faktor-faktor yang mempengaruhi tindakan manuusia terhadap lingkungannya akan memmpengaruhi terhadap pengelolaan lingkungan.

Bersadarkan penjelasan di atas maka peneliti ingin melihat apa faktor yang mempengaruhi pengelolaan lingkungan di bantaran hilir sungai
Musi di kecamatan Gandus kota Palembang. Hal ini disebabkan karena keadaan sebantaran sungai Musi belum sesuai dengan peraturan-perundangundang pengelolaan lingkungan yang berlaku. Berdasarkan masalah diatas tujuan dari penelitian ini adalah untuk mengetahui apa faktor-faktor yang dapat mempengaruhi pengelolaan lingkungan di bantaran hilir sungai Musi di Kecamatan Gandus kota Palembang

\section{METODOLOGI PENELITIAN}

Lokasi penelitian ini dilakukan kecamatan Gandus dan tepatnya di Bantaran Sungai Musi dikelurahan 36 Ilir, Karang Anyar, Karang Jaya, Gandus dan Pulo Kerto. Lokasi ini berada dipinggiran sungai Musi dan rumah-rumah yang berada di bantaran sungai Musi atau berdekatan dengan sungai dan bahkan ada rumah yang tiangnya berada di dalam sungai.

Metode yang di gunakan dalam penelitian ini adalah metode kualitatif dengan pendekatan deskkriptif empirik yaitu cara atau metode yang dilakukan yang biasa diamati oleh indera manusia, sehingga cara atau metode yang digunakan tersebut bias diketahui dan diamati juga orang lain (Sugiono: 2013).

Teknik pengumpulan data yaitu dengan menggunakan Angket untuk disebarkan ke sempel populasi yang berada di bantaran sungai Musi kecamatan Gandus. Observasi yaitu melakukan pengamatan dan pencaatan hal-hal yang penting serta dokumentasi gunanya untuk merekam, mengumpukan, mencatat, data-data yang didapat baik sebagai data primer atau sekunder.

\section{HASIL dan PEMBAHASAN}

\section{Hasil Penelitian}

Faktor Sosial Ekonomi Yang Dapat Mempengaruhi Pengelolaan Lingkunga dalam hal ini indicator yang dipakai adalah tingkat pendidikan, mata pencaharian, dan kepemilikan rumah, dan perilaku masyarakat. Untuk lebih jelas dapat kita lihat hasil penyebaran angket ke daerah penelitian Kecamatan Gandus kota Palembang adalah sebagai berikut. 
Tabel 1. Tingkat Pendidikan

\begin{tabular}{lcc}
\hline Tingkat Pendidikan & $\begin{array}{c}\text { Jumlah } \\
\text { responden }\end{array}$ & prosentase \\
\hline SD/Tidak Tamat SD & 32 & $64 \%$ \\
\hline SMP & 12 & $24 \%$ \\
\hline SMA & 8 & $16 \%$ \\
\hline Jumlah & 50 & $100 \%$ \\
\hline
\end{tabular}

Tabel.2. Tingakat Pekerjaan

\begin{tabular}{lcc}
\hline \multicolumn{1}{c}{ Jenis Pekerjaan } & $\begin{array}{c}\text { Jumlah } \\
\text { responden }\end{array}$ & prosentase \\
\hline $\begin{array}{l}\text { Buruh/kuli/tdk } \\
\text { bekerja }\end{array}$ & 43 & $86 \%$ \\
\hline $\begin{array}{l}\text { Wira } \\
\text { usaha,pengusaha, } \\
\text { karyawan }\end{array}$ & 6 & $12 \%$ \\
\hline PNS/TNI/Polri & 1 & $2 \%$ \\
\hline Jumlah & 50 & $100 \%$ \\
\hline
\end{tabular}

Tabel 3.Status Kepemilikan Rumah

\begin{tabular}{lcc}
\hline Kepemilikan rumah & $\begin{array}{c}\text { Jumlah } \\
\text { responden }\end{array}$ & prosentase \\
\hline Hak Milik & 31 & $62 \%$ \\
\hline Warisan & 10 & $20 \%$ \\
\hline $\begin{array}{l}\text { Kontrak/Milik } \\
\text { Pemerintah }\end{array}$ & 9 & $18 \%$ \\
\hline Jumlah & 50 & $100 \%$ \\
\hline
\end{tabular}

Table 4. Pemanfaatan sungai bagi masyarakat

\begin{tabular}{lcc}
\hline Jenis Manfaat & $\begin{array}{c}\text { Jumlah } \\
\text { responden }\end{array}$ & prosentase \\
\hline $\begin{array}{l}\text { Mandi, cuci, } \\
\text { Industri }\end{array}$ & 41 & $82 \%$ \\
\hline Air Minum & & \\
\hline Transportasi & 9 & $18 \%$ \\
\hline Jumlah & 50 & $100 \%$ \\
\hline
\end{tabular}

Hasil yang didapat adalah berdasarkan Pendidikan 64\% dari jumlah sampel yang diambil adalah berpendidikan terakhir tamatan SD atau Tidak Tamat SD. $86 \%$ dari angket yang disebarkan untuk semua sempel memiliki pekerjaan Buruh/Kuli/tidak bekerja. Uuntuk status kepemilikian rumah $62 \%$ dari sempel yang diambil rumah yang ditempati adalah hak milik, sedangkan untuk prilaku masyarakat. dalam hal ini hasil yang didapat bahwa dari prilaku masyarakat terhadap lingkungan adalah prilaku masyarakat membuang sampah pada tempatnya 58\% lahan terbuka $32 \%$ dan sungai $10 \%$, prilaku masyarakat dalam pembuangan limbah/WC 78\% di septic tang dan 22\% membuang langsung ke Sungai, perilaku manusia dalam hal pemanfaatan sungai adalah yang memanfaatkan sungai untuk mandi, cuci dan industri $82 \%$ dan memanfaatkan sungai sebagai transportasi $18 \%$ dan untuk air minum tidak ada yang memanfaatkannya. Hasil yang didapat ada beberapa yang menunjukkan siknifikan terhadap kualitas lingkungan.

\section{Pembahasan}

Kecamatan Gandus adalah salah satu kecamatan di Kota Palembang yang paling ujung terbagi atas 5 kelurahan yaitu Pulokerto, Gandus, Karang Jaya, Karang Anyar dan 36 Ilir. Rata-rata jiwa per keluarga di Kecamatan Gandus adalah 4. Tertinggi rata rata jiwa per keluarga di Kelurahan Gandus yaitu 4,74 jiwa/ keluarga dan terendah di Kelurahan Karang Anyar yaitu 4,07 jiwa/ keluarga. Hal ini disebabkan jumlah keluarga di Kelurahan Gandus lebih sedikit dan jumlah penduduknya lebih banyak. Sedangkan di Kelurahan Karang Anyar jumlah penduduk dan jumlah keluarga agak lebih banyak. (BPS. 2016)

Kepadatan Penduduk di Kecamatan Gandus menurut kelurahan bisa dikatakan hampir tidak merata. Kepadatan tertinggi ada di Kelurahan 36 Ilir dan terendah ada di Pulokerto. Hal ini disebabkan luas lahan di Kelurahan 36 Ilir lebih kecil (93 Ha) dari pada Kelurahan Pulokerto (3419 Ha). Meskipun jumlah penduduk di Kelurahan Pulokerto dan 36 Ilir hampir sama yaitu 12524 jiwa dan 12564 jiwa. (BPS.2016)

Pengaruh Faktor Sosial Ekonomi terhadap kualitas pengelolaan lingkungan. Pengelolaan lingkungan adalah upaya sistematis dan terpadu yang dilakukan untuk melestarikan fungsi lingkungan hidup dan mencegah terjadinya pencemaran dan/atau kerusakan lingkungan hidup yang meliputi perencanaan, pemanfaatan, pengendalian, pemeliharaan, pengawasan, dan penegakan hukum. (UU. 32 .2009)

Pengelolaan lingkungan awalnya kegiatan manusia masih sangat sederhana dalam memanfaatkan lingkungan hidup dan kegiatan yang dilakukan tidak menimbulkan dampak bagi lingkungan itu sendiri. Namun kegiatanan manusia yang intensif untuk mmemenuhi kebutuhannya dengan memanfaatkan lingkungan tanpa memperhatikan kondisi-kondisi lingkungan 


\begin{tabular}{lcr}
\multicolumn{1}{c}{ mulailah $\quad$ dampak } & terjadi. & Masalah \\
pengelolaan lingkungan & hidup & adalah \\
permasalahan yang sangat & penting. & Karena \\
pengelolaan lingkungan hidup mencakup masalah \\
pengelolaan lingkungan bersifat fisik, ekonomi \\
maupun social budaya. (Dinarti Karsono).
\end{tabular}

\section{Faktor-faktor sosial ekonomi yang mempengaruhi kualitas dalam penegelolaan lingkungan.}

Fakot-faktor yang menjadi indikator dalam penelitian ini adalah tingkat pendidikan, mata pencaharian, dan kepemilikan rumah, serta perilaku masyarakat.

Tingkat pendidikan, dari hasil analisis yang didapat bahwa tingkat pendidikan masyarakat yang tamat Sekolah Dasar atau Tidak Tamat Sekolah Dasar adalah sebanyak $64 \%$ hal ini menunjukan masih rendahnya tingkat pendidikan yang ada dalam masyarakat tersebut. Dengan rendahnya tingkat pendidikan masyarakat makin rendahnya pengetahuan masyarakat tentang tata cara pengelolaan lingkungan dan bila tingkat pendidikan masyarakat tinggi maka lingkungan masyarakat sekitar tempat mereka tinggal akan lebih terjamin.

Berdasarkan hasil pengamatan lapangan lingkungan yang terdapat di daerah penelitian sangat siknifikan, bahwa lingkungan yang menjadi daerah penelitian kecamatan Gandus sampah bertebaran di bantaran sungai Musi. Walaupun hasil angket tentang prilaku masyarakat meunjukkan pembuangan sampah pada tempatnya menunjukan bahwa $50 \%$ dan masyarakat membuang sampah ditempat terbuka $32 \%$. dapat lihat gambar. 1. Sesuai dengan pendapat dari Dinarti Karsono dalam penelitiannya di Perumahan Nasional Mojosongo Surakarta makin tinggi tingkat pendidikan orang maka berbagai macam kelebihan dapat dilakukan dalam mengatasi dan memecahkan permasalahan khususnya pengelolaan lingkugnan.

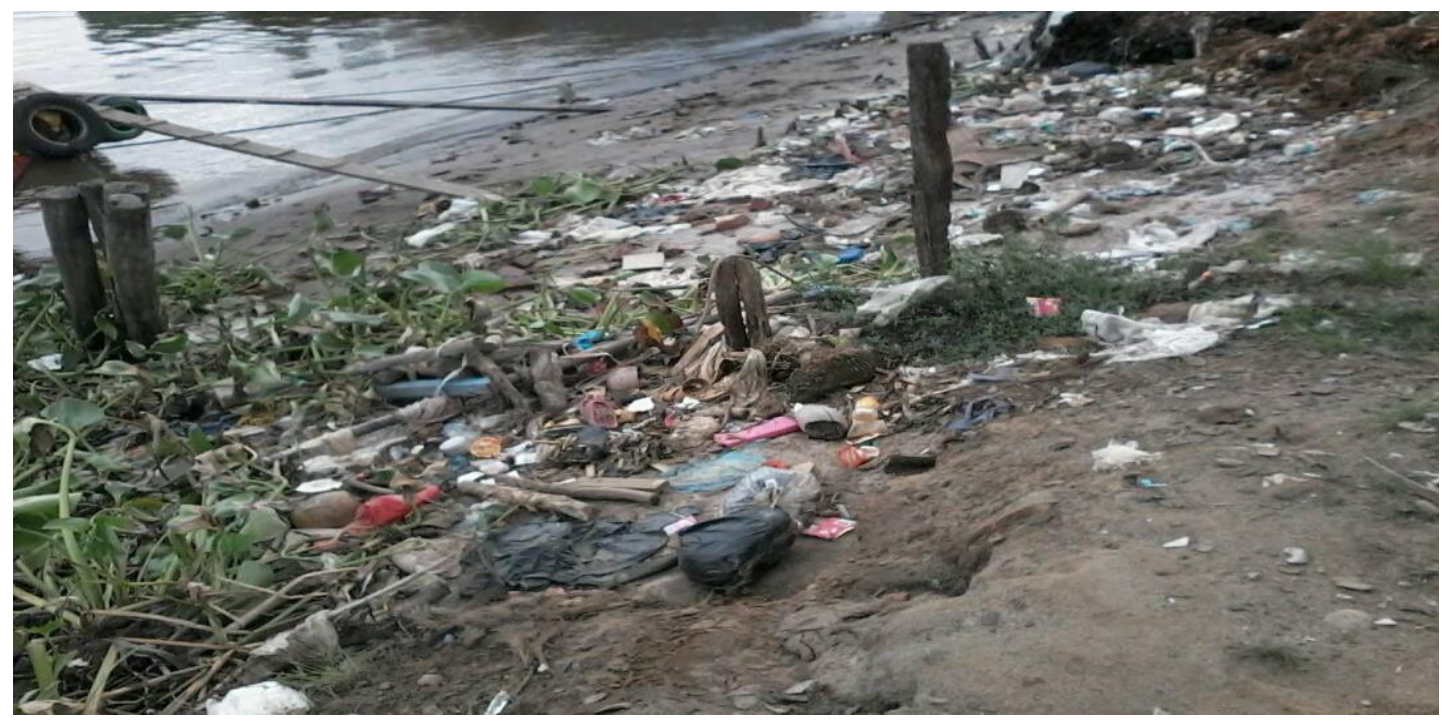

Gambar 1. Sampah bertebaran di Bantaran Sungai Musi (Sumber : Penelitian 2017)

Hasil angket Masyarakat yang menjadi sampel penelitian menunjukan bahwa $86 \%$ pekerjaan Buruh/Kuli/tidak bekerja yang dimiliki masyarakat, dalam hal ini berarti masyarakat pendapatan rendah. Biasanya bagi mereka yang berpendapatan rendah bagaimana dapat memikiran lingkungan sedangkan kehidupannya mereka belum dapat mereka tanggulangi. Hal ini menunjukan makin rendah pendapatan masyarakat makin rendah pengelolaan lingkungan yang dapat dilakukan dan makin tinggi pendapatan masyarakat makin banyak kesempatan masyarakat untuk berbuatan dalam pengelolaan lingkungan.

Status kepemilikian rumah $62 \%$ dari sempel rumah adalah hak milik. Dengan kepemilikan rumah seharusnya masyarakat harus lebih bisa memelihara lingkungan sekitar, tapi pada kenyataanya prilaku masyarakat membuang sampah lahan terbuka 32\%. Padahal seharusnya masyarakat dengan status kepemilikan rumah hak 
milik dapat lebih menjaga lingkungan tempat tinggalnya, karena mereka yang ditinggal disana bukanlah sementara tetapi bisa dikatakan untuk selamanya. Walaupun masyarakat yang tinggal di bantaran sungai membuanga sampah ke sungai hanya $10 \%$ tapi pada kenyataannya sungai tersebut tetap masih tercemar.

Sesuai dengan hasil peneitian pemantauan yang dilakukan oleh Badan Lingkungan Hidup dan Pertahanan (BLHP) sepanjang tahun 2016 bahwa sungai Musi sudah tercemar bakteri-bakteri ecoli. Bakteri ecoli ini muncul karena hasil pembuangan kotoran manusia atau tinja. (Kabar Legislatif. 2017) Hal ini berbanding terbalik dengan angket yang menyatakan bahwa masyarakat dalam pembuangan limbah/WC 78\% di septic Tang dan $22 \%$ membuang langsung ke Sungai. Hasil observasi bahwa masyarakat masih membuang limbah WC langsung ke sungai Musi. Untuk lebih jelas dapat kita lihat Gambar 2.

Sepanjang tahun 2016 dari hasil pemantauan yang telah dikelola, kondisi Sungai Musi sudah
$50 \%$ tercemar berat. Menurut arison yang didampingi Kasi Pengelolahan Sampah B3, dan Ali Husin pada Minggu 8 November 2017 dari hasil laboratorium terhadap kualitas air sungai yang berada di provinsi Sumater Selatan pada 2016, hasil pengujian menunjukkan parameter melebihi baku mutu, seperti ecoli, zat besi dan deterjen (Kabar Legislatif. 2017). Selanjutnya perilaku masyarakat dalam hal pemanfaatan sungai adalah yang memanfaatkan sungai untuk mandi, cuci dan industri $82 \%$ dan memanfaatkan sungai sebagai transportasi $18 \%$ dan untuk air minum tidak ada. Pemanfaatan sungai Musi yang telah tercemar semacam ini tidak hanya menggangu kualitas lingkungan tetapi dapat menggangu kesehatan masyarakat setempat kususnya masyarakat yang tinggal di bantaran Sungai Musi kecamatan Gandus Kota Palembang.. Dari hasil pembahasan diatas bahwa faktor-faktor sosial ekonomi dapat mempengaruhi kualitas penglolaan lingkungan, karena antara faktor faktor tersebut saling berkaitan satu sama lain.

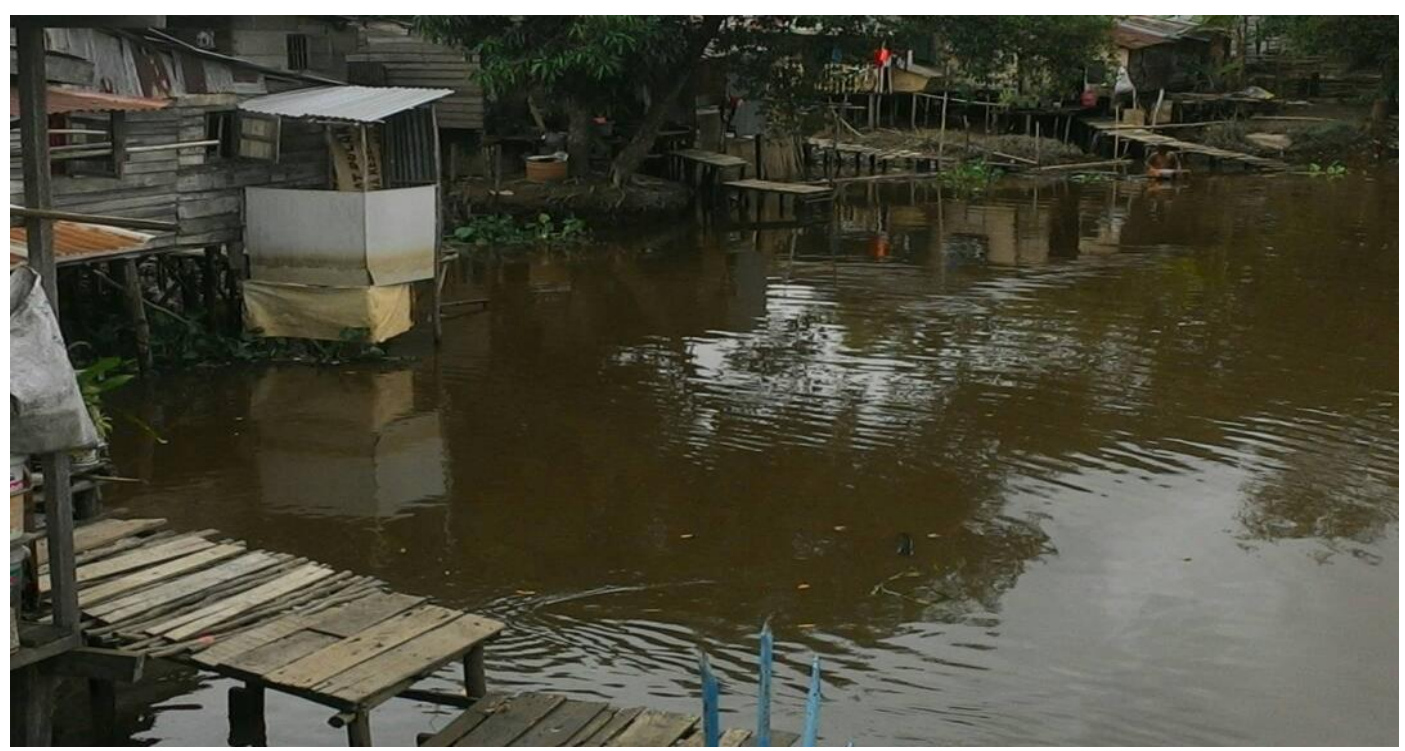

Gambar 2. Jamban atau WC yang membuangannya langsung kealiran sungai Musi

(Sumber : Mega, Helfa, Ratna penelitihan 2017)

\section{KESIMPULAN}

Dari hasil pembahasan diatas maka dapat disimpulkan bahwa faktor-faktor sosial ekonomi dapat mempengaruhi kualitas pengelolaan lingkungan. Dan faktor-faktor tersebut saling berkaita satu sama lain. Tingkat pendidikan yang rendah yaitu taman SD atau tidak tamat SD 64\%, memiliki pekerjaan sebagai buru/kuli/tidak kerja $86 \%$, kepemilikan rumah $82 \%$, dan perilaku masyarakat dalam membuang sampah dilahan terbuka $32 \%$, memanfaatkan sungai sebagai tempat mandi, mencuci, dan industri sebanyak $82 \%$ dan membuang limbah WC langsung kesungai $22 \%$. Jadi dari hasil persentase dengan 
kenyataan di lapangan bahwa terdapat mempengaruhi faktor sosial ekonomi terhadap kualitas pengelolaan lingkungan.

\section{DAFTAR PUSTAKA}

BPS. 2016. Statistik Daerah Kecamatan Gandus. Kota Palembang

Danarti Karsono. Faktor Faktor yang Mempengaruhi Sikap Masyarakat Dalam Pengelolaan Lingkungan di . Perumahan Mojosongko Surakarta portalgaruda.org/article.php. (akses 24 Januari 2018).

Husnah. 2010. Dinamika Fisik Kimia Perairan Sungai Musi. Perikanan Perairan Sungai Musi Sumatera Selatan. Balai Riset Perikanan Perairan Umum. Monograf. Desember 2010

Husnah. 2010. Degradasi Lingkungan dan Pencemaran di Sungai Musi. Perikanan Perairan Sungai Musi Sumatera Selatan. Balai Riset Perikanan Perairan Umum. Monograf. Desember 2010
Kabar Legislatif. 2017. Pencemaran Sungai Musi Masuk Dalam Katagori Berat . Edisi V Tahun 2017

Mega, Helfa, Ratna. 2017. Analisis Pengaruh Aspek Lingkungan dan Fisik Terhadap Kondisi Masyarakat Hilir Sungai Musi Kecamatan Gandus Kota Palembang. Jurnal Swarnabhumi. Volume 2. Nomor 2 ISSN 2548-5563. Agustus 2017.

Neolaka,A. 2008. Kesadaran Lingkuangan. Rineka Cipta. Jakarta

Ngurah N., Wiadnyana., dan Husna. 2010. Pendahuluan Perikanan Perairan Sungai Musi Sumatera Selatan. Balai Riset Perikanan Perairan Umum. Monograf. Desember 2010

Undang-Undang No 32 Tahun 2009.tentang Perlindunggan dan Pengelolaan Lingkungan Hidup.

.2016. Pengertian Emperis Dan contohnya Definisi Menurut Para ahli. www.definisimenurutparaahli. Akses 20 Februari 2018 